\title{
An Authentic Learning Environment Based on Video Project among Arabic Learners
}

\author{
Azman Che Mat (Corresponding author) \\ Universiti Teknologi MARA, Dungun Campus, Terengganu, Malaysia \\ E-mail: azmanchemat@yahoo.com \\ Azarudin Awang \\ Universiti Teknologi MARA, Dungun Campus, Terengganu, Malaysia \\ Ahmad Zulfadhli Nokman \\ Universiti Teknologi MARA, Dungun Campus, Terengganu, Malaysia
}

Nurshaifura Musilehat

Universiti Teknologi MARA, Kuala Terengganu Campus, Terengganu, Malaysia

Ahmad Fakrulazizi Abu Bakar

Universiti Teknologi MARA, Kuala Terengganu Campus, Terengganu, Malaysia

Received: 06-12-2016

Accepted: 21-02-2017

Advance Access Published: April 2017

Published: 01-07-2017

doi:10.7575/aiac.ijalel.v.6n.4p.143

URL: http://dx.doi.org/10.7575/aiac.ijalel.v.6n.4p.143

This work was fully supported by UiTM registered under: 600-IRMI/DANA 5/3ARAS (0105/2016).

\begin{abstract}
Role playing is among the language activities that stimulate language learners to use the language they are learning. However, a successful activity is always challenging especially when the learners are beginners. Therefore, a special arrangement needs to be carried out by instructors. This article explores the use of storyboards, or 'PCVA', to help Arabic learners prepare for their video project based on role playing. Blended methods were used to collect data, namely surveys, interviews, and observations. The target participants were among degree students from second level (TAC451) and third level (TAC501) of Arabic course. The total number of the participants is 87 respondents. Interview and observation were conducted during consultation period and then, related information was documented for the purpose of the study. Descriptive analysis was implemented to interpret the data. The findings showed a positive feedback from the learners who were involved in the experiment.
\end{abstract}

Keywords: Role Play, Storyboard, Arabic Learners

\section{Introduction}

Video project is a compulsory task for every Arabic language student in UiTM. The project preparation involves all students at every level under the course code TAC (401, 451 \& 501). The end product of the project was evaluated in two parts: development of the script and the completed video submitted to their respective lecturers (Academy of Language Studies, 2012).

Video has become a medium of learning and is given the utmost attention by specialists in education, especially in the ICT field. In this case, the technical skills needed to ensure the process of recording, editing, and delivery of the complete assignments can be carried out within the prescribed period.

This study believes that video project has positive implications for authentic learning. Authentic assignments involving 'life situations' require students to make decisions, which expose them to real-world information (CTGV, 1990). In addition, this assignment also provides space for students to understand and identify their problems and finally solve them.

There are two models for authentic learning: simulation and participation (Radinsky, Josh, et al., 1998). The simulation model is based on a situation created in class, but still provides real-life context. Therefore, students can practise their language, which they may encounter in real-life situations. For simulation model, instructors must give serious attention and provide appropriate supportive materials prior the class session.

Whereby in participation model, students need to participate in a real-life situation. They need to communicate directly with the public and be involved in activities undertaken by the community. This model is known as ecological authentic 
(Barab, et al., 2000), because students are directly involved with real activities carried out by the community (Lave, et al., 1991).

This will be benefited to be shared among Arabic language educators, researchers, and students on the use of storyboard for video projects. Storyboard is used as a medium of teaching and learning Arabic language among students at UiTM Terengganu. The term PCVA (in Malay is: Papan Cerita Video Arab) is used to refer to the storyboard. Upon their submission of the projects, language assessment for their performance in the video will be carried out by their lecturers.

\section{Brief Review of the Study}

Engaging and effective learning is a goal in education. Interesting and effective learning process should be planned by instructors by applying a variety of approaches, methods, and techniques while delivering learning content. The background of the students involved in the teaching and learning (TL) process should be considered before any approach is implemented, in addition to the syllabus in accordance with the general and specific objectives of language learning.

In the context of language learning, which emphasises on practical skills, instructors need to achieve their objectives, while students need to use the language in the appropriate context. Some approaches were specially chosen to perform this task. As a practical matter, language instructors must be able to prepare their students with speaking skills just like other skills such as carpentry and art.

Learning Arabic has been progressing. This is clearly evident in particular in teaching approach, whereby it is given serious consideration by various parties, especially educational institutions such as schools and universities. Arabic teaching is no longer limited to linguistic sciences such as grammar, morphology, and rhetoric. In fact, Arabic has been given a new approach called 'Communicative Arabic.'

In the language acquisition theory, humans began to use languages using their speech skills. Only then they moved to writing skills. According to Khalilullah, M. (2012), verbal skills are a priority in the process of language acquisition, especially foreign languages such as Arabic. In fact, a person is considered not proficient if he/she is not able to converse well in face-to-face communication. Therefore, writing is a form of high-level skill, as students need to master the symbols of a language that represent the sounds of a language.

Arabic communication is taught to ensure that students can use Arabic in their daily lives. Basic utterances in Arabic communication need to be taught to students so that they can acquire it better. Despite that, functional grammar of Arabic language is not ruled out altogether.

Academically speaking, students do not have problems communicating in Arabic (Ismail, et al., 2012). However, the problem is the practice of instructors who do not meet the objectives of teaching Arabic Communication (Ismail, et al., 2011). Therefore to achieve a learning objective successfully, many aspects should be taken into considerations. Beside student and instructor, language activities (game, role play etc.) are playing critical function to contribute for student learning input. Wan Hasmah and Nur Munirah (2015) asserted that using game or simulation in the classroom will develop active interaction between instructor and student.

Role play is one of the most popular activities in language teaching. Olusegun (2004) mentioned that role-playing has been proclaimed as a powerful technique used in the upper level of cognitive domain of learning especially in both individual and group situations. It involves students to participate as actors and play as certain characters. In the context of Arabic learning in particular, it is a very useful language activity, as Arabic is often considered as a difficult subject to learn (Siti Salwa, et al., 2012).

As mentioned by Abdul Rahim Abdul Rashid (2000), if the role play activity is controlled vehemently it will be an effective teaching method. Role play requires teachers to be really prepared to allow students to carry out this activity successfully. Teachers also need to achieve the objectives after the activities were successfully implemented. The next evaluation is done as a measurement and for the purpose of improvement.

\section{Problem Statement and Research Objectives}

Video preparation without proper guidance and supervision will lead to unexpected learning outcomes. This is reasonable when in certain cases students are not really well-versed to use Arabic expression in a particular context. Some students tend to rely on translation machine such as Google translate to translate their works, which end up with weird and bad mistakes.

Preparation without supervision and proper guidance will lead to unsatisfactory outcomes. Some students may not know when an utterance is suitable in certain situations. Some of them may have also used online translation services for direct translation of the script, which includes mistakes. Therefore, the researchers intend to formulate a structured process for the preparation of this project, which has been innovated in accordance with the project objectives and is carried out as follows:

1. To identify the students' acceptance of the PCVA process implemented for video tasks,

2. To identify the advantages and disadvantages of PCVA in the context of improving the implementation of this project. 


\section{Methodology}

This research is exploratory in nature. The researchers have considered previous contexts, which indicated some misconduct by students in preparing their final project. In this sense, researchers have assigned one semester for degree students to follow the guideline, and supervised by a lecturer. The process is as follows:

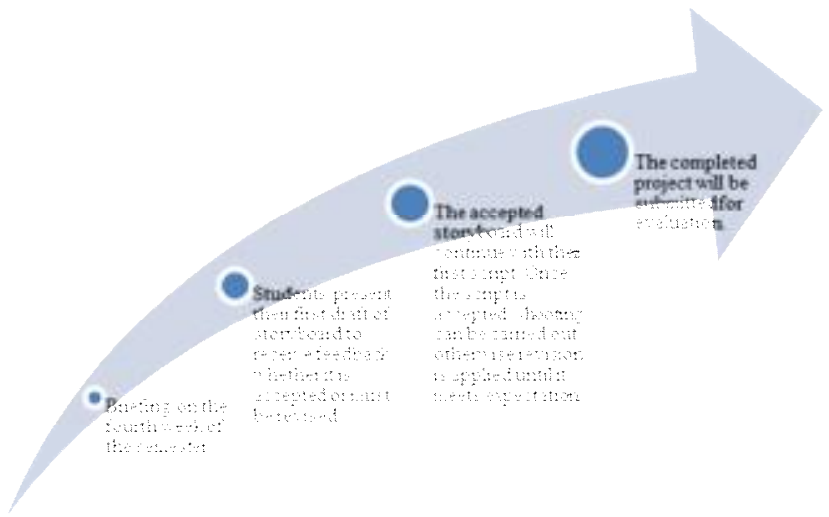

Figure 1. The Process of Video Project Preparation

1. Briefing session took about 10-15 minutes, supported by presentation of previous video projects to get some ideas. Presentation was believed to be a source of inspiration for students for their own projects.

2. The first draft of the storyboard by the group was presented outside the lecture's time. An appointment was set early before the presentation could proceed. All group members were required to attend the presentation to contribute ideas and share their views. If the story was suitable and appropriate with their course level, the consent will be awarded and the group will continue to the next stage. Otherwise, they have to revise their storyboard until they meet the expectation of the lecturer.

3. The script that accompanied the storyboard was reviewed by the lecturer. Some recommendations were suggested to ensure that the content of the project is in line with the objectives to offer an authentic environment for students to practise their language skills. Once the script was accepted, the group was permitted to work on their project until completed.

4. The completed project must be submitted during the study week. Any late submission would affect the group's marks as mentioned in the course syllabus.

Therefore, at the end of the semester, pre-post self-developed questionnaire was distributed to the respondents. They already went through the process and have some characteristics determined by the research objectives. Finally, descriptive analysis was done by using IBMSPSS 21 to obtain frequency and mean score from collected questionnaire.

As for interview method, unstructured questions were applied to the students who are the members of the group during their consultation period. At the same time, observation of their works especially their initial draft for role playing were recorded and documented for the purpose of this study. However the number of the participant for interview session was not counted.

\section{Findings}

This section reports the findings of the study based on previous discussion. The discussion in this section is divided into two, namely the findings of the questionnaire, and interview and observations.

Table 1. Respondent's distributions

\begin{tabular}{lccc}
\hline Gender & \multicolumn{2}{c}{ Course code } & Total \\
& TAC451 & TAC501 & \\
Male & 1 & 5 & 6 \\
Female & 29 & 52 & 81 \\
\hline $\mathrm{N}$ & 30 & 57 & 87 \\
\hline
\end{tabular}

Table 1 shows the background of respondents. A total of 87 participants responded to the questionnaire. They consisted of six male students and 81 female students. Course levels also showed that TAC501 has more participation, with 57 students in total compared with TAC451 that had 30 students. This is because students for TAC501 also consisted of students who have taken Arabic language during their diploma at UiTM. They make up the majority, as the number of undergraduate students in the group is actually smaller than TAC451.

Table 2 shows the respondents' views on the implementation of the activities of PCVA for Arabic assignment. The 
highest mean (4.1954) showed that the respondents believed that these activities help add further information on the Arabic subject they received in the classroom.

This was followed by the view that the activity further clarifies the subject and that it is also fun (4.1034). Respondents also felt that this activity should be continued (4.0345) and that they can ask directly about Arabic while performing this activity (4.0230). The lowest mean (3.6437) showed respondents felt that the program needs to be updated.

Table 2. Respondent's Views on PCVA

\begin{tabular}{cll}
\hline No. & Item & Mean \\
\hline 1 & This activity enriches my information of TAC subject & 4.1954 \\
2 & This activity further clarifies my knowledge on the TAC subject & 4.1034 \\
3 & This activity is fun & 4.1034 \\
4 & I feel that this activity should be conducted for the next semester & 4.0345 \\
5 & I can ask questions directly about Arabic & 4.0230 \\
6 & I think this program should be updated & 3.6437 \\
\hline & Average Mean & 4.0172 \\
\hline
\end{tabular}

Based on these findings, the researchers have conducted observations and interviews with several groups, and the feedbacks received include:

1. Students said they used several sources, especially dictionaries and online resources such as Google translate. This proved true when they translated the word 'Miss' or 'Madam' by ملكة الجمال. This translation is available in online sources. This finding has supported previous studies on the use of google translate among UiTM students in Shah Alam main campus. As cited in the works of Asma' and Naimah (2014), a lot of linguistic errors found in the most of students video projects such as verbs, words agreement, particles and expression. Therefore they recommended Arabic lecturers to advise their students regarding the shortcomings from using this online resource.

2. Students agreed that they received help from seniors to write scripts in Arabic. In addition, they also looked for group members who have a background in Arabic in secondary schools. Implicitly, PCVA implementation has encouraged students to give more efforts to complete their video project. As mentioned by Oxford (1987), among language learning strategies used by learners is socio strategy. In this regards, receiving a help and guide from seniors to complete their video projects was considered a part of learning strategy.

3. In addition, when students come for supervisory purposes assignment, they discovered new words but they had difficulty pronouncing them properly. Researchers provided assistance and let them practice the correct pronunciation before the recording started. In this part, students were motivated to meet their lecturers and discuss closely about their learning problems and find a solution. Students with this motive were categorized as using metacognitive strategy by looking for people he/she can talk to in second language (Oxford, 1987).

4. There are suggestions from students that supervisory sessions should only be run once. This is because they feel burdened by this meeting.

The results obtained before and after the experiment was carried out showed a significant difference. Table 3 below shows the overall mean difference of the level of knowledge and attitude before and after the experiment by using storyboard based on the feedback of the respondents.

Table 3. Before and After the Implementation of PCVA

\begin{tabular}{cccc}
\hline Item & Minimum & Maximum & Mean \\
KLB & 1.00 & 5.00 & 2.3333 \\
KLA & 3.00 & 5.00 & 3.9080 \\
ABE & 1.00 & 5.00 & 3.0690 \\
AAF & 3.00 & 5.00 & 4.2989 \\
\hline
\end{tabular}

*KLB: Knowledge Before

KLA: Knowledge After

ABE: Attitude Before

AAF: Attitude After

Based on the table above, the mean score of previous knowledge is 2.3333 . However, after the students went through the PCVA, the mean score is higher, which is 3.9080. Similarly, the mean score for attitude before PCVA was lower 
(3.0690) compared with the mean score after PCVA (4.2989). The findings of this survey have also been reinforced by data collected through observations and interviews. The researchers have made some conclusions, as below:

1. According to the respondents, they are vague about the score assigned to this task. Through supervision sessions, the researchers explained about the score further.

2. Initially, the respondents had difficulties in distributing tasks for each member of the group. However, when PCVA was implemented, they managed to work on the tasks, and the processes that occurred in every movement of the work were done smoothly.

3. Through the PCVA also respondents admitted that they are not sure what exactly the objectives of this assignment were. When they went through this experiment, they were briefed in detail by the researchers. Finally, their understanding became better rather than only through a briefing in the classroom or reading a paper sheet guide. 4. Respondents also said they were able to work more regularly when using the PCVA. Guided by the PCVA, they can sit down together and exchange opinions to complete this task in the given period.

5. They also agreed and contented when given guidance and supervision by the lecturer. Minor errors were found but that aided them to be more careful when making the initial script. In addition, the use of online resources was monitored frequently.

\section{Conclusion}

Based on the above discussion, it can be concluded that the use of PCVA as a medium for learning Arabic is a significant task. Highlights from this study can be explained through the implications of these studies, namely:

1. Media learning of Arabic using PCVA should be promoted to ensure students have the necessary guidance from instructors,

2. Consider time allocation for instructor's guidance and consultation when setting up this task. Instructors will be able to give adequate attention to the groups involved,

3. Propose two hours for instructor's supervision when using the PCVA for the purpose of preparing this assignment. It is highly desirable because if this project is completed, but without any guidance, the students will not get the benefits of learning, for example seeking material from open sources such as the internet.

4. A study on a larger scale should be carried out specifically when involving all TAC course codes in the future. This would further give a more comprehensive picture on the needs of PCVA in the preparation of assignment.

5. The use of PCVA is expected to provide vast opportunity for student to apply language learning strategy such as metacognitive strategy. As reported by Takeuchi (2003), a good language learners use metacognitive strategies by maximizing opportunities to use the language, pushing oneself into using the language, learning intensively, learning regularly and having a concrete need/plan for learning.

\section{References}

Abdul Rahim Abdul Rashid, Abdul Aziz Abdul Talib, Abdul Ghafar Md. Din \& Mohamad Haron. (2000). Panduan latihan mengajar. Kuala Lumpur: Dewan Bahasa dan Pustaka.

Academy of Language Studies. (2012). TAC451\&TAC501 Syllabus. Shah Alam: UiTM.

Asma' Ammar and Naimah Abdullah. (2014). Isu penggunaan sumber teknologi maklumat di dalam terjemahan projek bahasa Arab dalam kalangan pelajar UiTM. In Liau Lay San et al. (eds). 3rd ILANNS: Issues in Language Teaching and Learning amongst Non-native Speakers. Academy of Language Studies, Universiti Teknologi MARA, Shah Alam. pp. 477-486.

Barab, S.A., Squire, K.D. \& Dueber, W. (2000). A co-evolutionary model for supporting the emergence of authenticity. Educational Technology Research \& Development, 48(2) 37-62.

CTGV (Cognition and Technology Group at Vanderbilt). (1990). Technology and the design of generative learning environments. Educational Technology, 31(5) 34-40.

Ismail, Azani, Azman Che Mat, and Mat Taib Pa. (2012). Membina kemahiran pertuturan menerusi aktiviti lakonan dalam pengajaran bahasa Arab. GEMA: Online Journal of Language Studies 12(1), 325-337.

Ismail, Zawawi, Nik Mohd Rahimi, Ab Halim Tamuri. Nik Yusoff \& Mohd Ala-Uddin Othman. (2011). Teknik pengajaran kemahiran bertutur bahasa Arab di SMKA di Malaysia. GEMA Online ${ }^{\mathrm{TM}}$ Journal of Language Studies 11(2), 67-82.

Khalilullah, M. (2012). Media Pembelajaran Bahasa Arab. Yogyakarta: Aswaja Pressindo.

Lave, Jean, and Etienne Wenger. (1991). Situated learning: Legitimate peripheral participation. Cambridge university press,

Olusegun, A.S. (2004). Efficacy of Role-Playing pedagogy in training: some reflections. Journal of Management Development., 23(4), pp. 355-371.

Oxford, R. L. (1989). Use of language learning strategies: A synthesis of studies with implications for strategy training. System, 17(2), pp. 235-247.

Radinsky, J., Bouillion, L., Hanson, K., Gomez, L., Vermeer, D., \& Fishman, B. (1998). A framework for authenticity: Mutual benefit partnerships. In annual meeting of the American Educational Research Association, San Diego, CA. 
Siti Salwa Mohd Noor, Norhayati Che Hat dan Norfadhilah Gazali. (2012). Penilaian Kemahiran Bertutur dalam bahasa Arab Melalui Kaedah Aktiviti Bahasa. In Kamarul Shukri Mat Teh, Zulazhan Ab Halim, Mohd Shahrizal and Nurazan Mohmad Rouyan (eds). Dinamika Pendidikan Bahasa Arab: Menelusuri Inovasi Profesioanlisme Keguruan. Kuala Terengganu: Penerbit Universiti Sultan Zainal Abidin. 99-114.

Takeuchi, O. (2003). What can we learn from good foreign language learners? A qualitative study in the Japanese foreign language context. System 31 (2003), pp. 385-392.

Wan Hasmah W. M. \& Nur Munirah T. A. (2015). Permainan dan simulasi. Kuala Lumpur: Dewan Bahasa dan Pustaka. 